\title{
Theorizing Ecclesial Ecocriticism: Pathetic Fallacy in Ecclesiastical Literature on Climate Change
}

\author{
André Kaboré \\ Department of Anglophone Studies, University of Ouagadougou, Burkina Faso
}

Copyright $\subseteq 2016$ by authors, all rights reserved. Authors agree that this article remains permanently open access under the terms of the Creative Commons Attribution License 4.0 International License

\begin{abstract}
The objective of this paper is to show the Catholic Church's concern with ecology in its literature, its use of literary devices to enhance an effective response to the call for nature's protection and to show to what extent one can hypothesize ecclesial ecocriticism as a theory different from its literary counterparts. The methodology that will be used is that of ecocriticism or green study; this paper is a stylistic investigation of the Catholic Church's discourse on climate change, namely Pope Benedict's encyclical letter Caritas in Veritate on Integral Human Development in Charity and in Truth (2009), and Pope Francis's encyclical letter Laudato Si on Care of our Common Home (2015). Reading these works, one becomes aware that Catholic Church leaders are engaged in a particular type of ecocriticism. How is this different from literary ecocriticism? And for what purpose do church leaders use literary figures in their discourse? These are the questions around which the discussion will be held. The paper will argue that there is an ecclesial ecocriticism endowed with its special characteristics. Our hypothesis is that the use of personification and pathetic fallacy in the two popes' works on nature leads to two types of pathetic fallacies, namely, humanization of nature and naturalization of the human being, thus strengthening this conception of nature as God's creation and gift to humanity, and thus efficiently pleading the latter for nature's protection.
\end{abstract}

Keywords Nature, Climate, Change, Morality, Ecocriticism, Catholic Church, Theory

\section{Introduction}

Concern for the environment or nature is increasingly the preoccupation of governments, politicians, scientists, writers, critics, and religious leaders. Newspapers headlines of the last two centuries are recurrent about "Oil spills, lead and asbestos poisoning, toxic waste contamination, extinction of species at an unprecedented rate, battles over public land use, protests over nuclear waste dumps, a growing hole in the ozone layer, predictions of global warming, acid rain, loss of topsoil, destruction of the tropical rain forest, controversy over the Spotted Owl in the Pacific Northwest, a wildfire in Yellowstone Park, medical syringes washing onto the shores of Atlantic beaches, boycotts on tuna, overtapped aquifers in the West, illegal dumping in the East, a nuclear reactor disaster in Chernobyl, new auto emissions standards, famines, droughts, floods, hurricanes, a United Nations special conference on environment and development, a U.S. President declaring the 1990s 'the decade of the environment,' and a world population that topped five billion" [1, p16].

This grim picture is timelessly relevant. Generations change but the pollution of nature remains identical or worsen. The solution to "the immediate problems of pollution, environmental decay and the depletion of natural resources," Pope Francis[2] says in Laudato Si (2015), a document on care for nature, demands a collaboration of many sciences and strategies, including "a distinctive way of looking at things, a way of thinking, policies, an educational program, a lifestyle and a spirituality which together generate resistance to the assault of the technocratic paradigm" [2, \#111]. He is convinced that "to seek only a technical remedy to each environmental problem which comes up is to separate what is in reality interconnected and to mask the true and deepest problems of the global system" [2, \#111]. His predecessor, Pope Benedict XVI, known as the 'Green Pope,' devoted a chapter on questions related to the environment in his Caritas in Veritate (2009). Prior to him, Pope John Paul II dealt with ecology in his encyclical letters Laborem Exercens (1981), Sollicitudo Rei Socialis (1987), Centesimus Annus (1991). In recent years, many Catholic bishops and Episcopal conferences [see 12] have issued ecological exhortations, excerpts of which appear in Laudato Si. Rarely do ecocritics consider such works, simply because of their religious context. It is against this hostile background that Pope Francis says that it is not "reasonable and enlightened to dismiss certain writings simply because they arose in the context of religious belief' [2, \#199]. But with which critical tools can we assess these particular works as the tools of literary ecocriticism seem inadequate? This 
explains the necessity of theorizing ecclesial theory of ecocriticism. It may help us get a deeper understanding of religious classics or literary texts written by religious people than general theory of ecocriticism do. On the other hand, it might also be useful when reading non-religious texts, as it valorizes ecological aspects in a way that secular ecocriticism doesn't.

In all of these ecologically-minded religious works, literary devices, especially personification and pathetic fallacy, that is, "the attribution of human emotions to works of nature" [3, p297], play important roles. Using the theory of ecocriticism or green studies, which "is the study of the relationship between literature and the physical environment" [3, p18], this paper is an attempt at addressing these concerns, namely the inadequacy of secular ecocriticism and religious texts.

Ecocriticism "seeks to warn us of environmental threats emanating from governmental, industrial, commercial, and neo-colonial forces" [4, p4580]. Examining the pathetic fallacy has been a long-standing element of ecocriticism; indeed John Ruskin, who coined the term 'pathetic fallacy,' was, in Barry[4]'s words, "deeply eco-conscious, the first major British writer to record a sense that nature's powers of recovery might not be infinite, and that modern form of production and consumption have the potential to inflict fatal environmental damage" [p4667]. This secular ecocriticism and the discussion on the pathetic fallacy will help us not only define the contours and particularities of ecclesial ecocriticism applicable to Catholic writings but also show that the use of literary devices, especially that of pathetic fallacy, is the expression of the extension of the self into the surrounding nature.

\section{Methodology}

The discussion proceeds by textual analysis of ecclesial literature on climate change, informed by the literary theory of ecocriticism, in a comparative perspective. Such comparative analysis expands the theory of ecocriticism used for literary texts and argues for a new theory, ecclesial ecocriticism, that would be much more suitable for nonliterary texts, namely religious ones. The ecclesial literature under consideration is namely Pope Benedict's encyclical letter Caritas in Veritate on Integral Human Development in Charity and in Truth (2009), and Pope Francis's encyclical letter Laudato Si on Care of our Common Home (2015).

\section{Results}

General literary ecocriticism is concerned with literary writings. As literature traces its roots to the hermeneutics of religion $[6, p 78]$, there is, not only a place, but a necessity, for the theory of ecclesial literary ecocriticism applicable to religion-related literature. The characteristic features of this new theory, upon examination and stylistic analysis of ecclesial literature on climate change, are the restoration of human nature within the other natures, the interdependence of natures, the attribution of the authorship of natures to God, and drawing an intrinsic relationship between nature's protection and one's belief in its origin. This theory of ecclesial ecocriticism then gives rise to two types of pathetic fallacies: one consisting in ascribing human traits to inanimate nature, and the other in the attribution of nature's potentials to human beings.

\section{Discussion}

\subsection{The Particularities of Ecclesial Ecocriticism as Theory}

The American term 'Ecocriticism', or the British equivalent 'green studies', is a relatively new theory in literary criticism. It started in the USA in the late 1980s, and in the UK in the early 1990s. Lawrence Buell, Ursula K. Heise, and Karen Thornber write, "Ecocriticism started as an organized movement within literature studies in the early 1990 s, a scholarly generation later than the first such movements within the environmental humanities (in history, ethics, and theology). Ecocriticism as a Library of Congress subject heading dates from 2002" [5, p433]. Yet, the ideas behind ecocriticism had been in circulation for much longer; three major nineteenth-century American writers-Ralph Waldo Emerson (1803-1882), Margaret Fuller (1810-1850), and Henry D. Thoreau (1817-1862)-could be seen as the founders of ecocriticism [4, p4542].

Ecclesial ecocriticism has been mainly developed by the last three popes (John Paul II, Benedict, and Francis), whose encyclical letters and exhortations, some of which are under consideration in this paper, are ecologically focused. These popes' writings are essentially essays in literary terms, and as such, may help us theorize an ecclesial ecocriticism as a method for analyzing Christian writings, because even though religion alongside other disciplines in the humanities has been 'greening' since the 1970s [1, p16], no formal ecologically-informed criticism has been developed as ecclesial ecocriticism, with its own principles and criteria.

Ecocriticism, as opposed to structuralist, post-structuralist, and historicist theories that usually perceives the external world as linguistically and socially constructed, calls this traditionally-established perception into question. Defining ecocriticism as a literary theory, the critic Peter Barry[4] asserts that ecocriticism "repudiates the fundamental belief in 'constructedness' which is such an important aspect of literary theory" [p4600] in general. He explains that, "for the ecocritic, nature really exists, out there beyond ourselves, not needing to be ironized as a concept by enclosure within knowing inverted commas, but actually present as an entity which affects us, and which we can affect, perhaps fatally, if we mistreat it. Nature, then, 
isn't reducible to a concept which we conceive as part of our cultural practice (as we might conceive a deity, for instance, and project it out onto the universe)." [4, p4590]

For example, social inequality can be 'naturalized', that is, disguised as natural or given. The ecocritic should not consider this kind of nature.

Sharing "the fundamental premise that human culture is connected to the physical world, affecting it and affected by it" [1, p19], one of the tasks of the ecocritic would be to demask such false natures and reveal the true one that is hidden under any culturally constructed nature. Hence, William Howarth defines the ecocritic from its Greek etymology (oikos=house and kritis=judge) as "a person who judges the merits and faults of writings that depict the effects of culture upon nature, with a view toward celebrating nature, berating its despoilers, and reversing their harm through political action" [6, p69].

The particularity of the Catholic Church's social teaching is that nature is not only "the setting for our life" (Benedict 48) but it includes human nature. While "Ecocriticism expands the notion of "the world" [from being synonymous with society] to include the entire ecosphere" $[1, \mathrm{p} 19]$, the Church leaders expand nature to include human nature. Rather than considering the human being as separate from the world, the resources of which this latter uses, the Church deals with the individual as a component of it, that is, the individual in the environment. In nature we find human nature and many other natures that are different from each other. Pope Francis[2] lays a strong emphasis on the fact that "human beings too are creatures of this world" [\#43] and that "nature cannot be regarded as something separate from ourselves or as a mere setting in which we live. We are part of nature, included in it and thus in constant interaction with it" $[2, \mathrm{p} 139]$. So, inclusion of human nature in nature can be considered as fundamental in ecclesial ecocriticism. This theory shows how the human might be seen as part of nature, without simply giving the human primacy.

The critic Evernden was critical of general ecocriticism for separating the human being from the environment. He says that "rather than thinking of an individual spaceman who must slurp up chunks of the world-'resources'-into his separate compartment, we must deal instead with the individual-in-environment, the individual as a component of, not something distinct from, the rest of the environment" [8, p18]. He further explains that it is only in the inclusion of human nature within the environment that one can account for literary metaphors and other literary devices such as personification and pathetic fallacy: "Once we engage in the extension of the boundary of the self into the 'environment' then of course we imbue it with life and can properly regard it as animate-it is animate because we are part of it. And following from this, all the metaphorical properties so favored by poets make perfect sense: the Pathetic Fallacy is a fallacy only to the ego clencher. Metaphoric language is an 'indicator' of 'place'-an indicator that the speaker has a place, feels part of a place." [8, p18].
The pathetic fallacy only seems wrong to those who want to see the ego, the individual, as completely autonomous and separate from the outside world. The Church leaders, in their writings, advocate a natural place of human nature within the environment, not a metaphorical one. The Church's teaching presents the human being as naturally part of nature. As an element among many others in the environment, and considering the interaction between natures, Pope Benedict XVI[7] could say that "the way humanity treats [other natures in] the environment influences the way it treats itself, and vice versa" [\#51]. The protection of the environment and that of human life cannot be separated. Nature is cared for when man takes care of himself responsibly.

The second particularity of ecclesial ecocriticism is that of the interdependence of natures within the environment. Pope Francis[2] underlines many times in Laudato Si his conviction that "everything is interconnected" or interrelated [\#16, 42, 70, 91, 117, 138, 240], and that "we are not disconnected from the rest of creatures, but joined in a splendid universal communion" [\#220]. The Pope makes explicit here what was already said in the Catechism of the Catholic Church: "God wills the interdependence of creatures. The sun and the moon, the cedar and the little flower, the eagle and the sparrow: the spectacle of their countless diversities and inequalities tells us that no creature is self-sufficient. Creatures exist only in dependence on each other, to complete each other, in the service of each other" [2,\#340]. Any human being lives in interaction with what Heidegger calls "the fourfold," that is, fellow mortals, the earth, the sky, and the divinities. Kate Rigby[9] explains that Heidegger's "fourfold comprises earth, understood as the land itself with its particular topography, waterways, and biotic community; sky, including the alternation of night and day, the rhythm of the seasons, and the vagaries of the weather; divinities, those emissaries or traces that yet remain of an absent God; and, last but not least, mortals, fellow humans" [p430]. Human life is interwoven with the earth, the sky, God, and other fellow humans. This interdependence of natures, according to the Creator's will, is one of the key components of ecclesial ecocriticism.

Interconnectivity within nature necessarily entails the presence of many different natures. Ecology applies then to the nature of any creature; hence, the ecology of the environment, of animals, of man and woman, and so on and so forth. It is in this perspective that Pope Benedict[7] speaks of an "ecology of man", grounded on the fact that "man too has a nature that he must respect and that he cannot manipulate at will" [\#155]).

A third constitutive element of ecclesial ecocriticism is the attribution of a common author, namely God, to all natures. It follows that if all natures have a common genitor, they are all related to each other. We can speak of 'universal fraternity' in this sense. This calls for fraternal love between all creatures. Observing that "fraternal love can only be gratuitous," Pope Francis[7] says that "this same gratuitousness inspires us to love and accept the wind, 
the sun and the clouds, even though we cannot control them" [\#228]. Consequently, the idea of a common creator leads to a sense of interconnection that is outside of hierarchy or traditional power schema.

A fourth and final feature of ecclesial theory of ecocriticism is linked to the theories around the origin of nature in general. In Caritas in Veritate, Pope Benedict $\mathrm{XVI}[7]$ makes the point that harm is done to nature as a result of the different conceptions people have about its origin. He includes the human being within nature, saying, "when nature, including the human being, is viewed as the result of mere chance or evolutionary determinism, our sense of responsibility wanes" [\#48]. He establishes a relationship between belief in the origin of nature and one's protection of it. One's conception of the origin of nature determines one's handling of it. If one believes that nature is the result of evolution beginning with a big bang, one believes that whatever damage one inflicts will but contribute to the world's continuous evolution, whether it is positive or negative. If nature came to exist by chance, it may disappear by chance. Such conceptions lead to nature's destruction without somebody to blame. Pope Benedict XVI is convinced that the root of nature's destruction lies in the lack of faith in God, as the author of creation lies, in "the notion that there are no indisputable truths to guide our lives, and hence human freedom is limitless. We have forgotten that man is not only a freedom which he creates for himself. Man does not create himself" [2, \#6]. The antidote to this destructive vision of an anthropocentric world is one, Benedict argues, in which faith is embraced and the interconnectedness of humans and the non-human world is revealed.

At an audience Pope Benedict XVI gave to Priests of Brixen, Karl Golser, a professor of moral theology in Brixen, and also director of the institute for justice, peace, and the safeguarding of creation, asked the Pope the following ecology-related questions: "What can we do to bring a greater sense of responsibility toward creation into the life of the Christian communities? How can we arrive at seeing creation and redemption increasingly as a whole?" In his answer, the Pope explicitly and clearly asserted that "The brutal consumption of Creation begins where God is not, where matter is henceforth only material for us, where we ourselves are the ultimate demand, where the whole is merely our property and we consume it for ourselves alone ... I think, therefore, that true and effective initiatives to prevent the waste and destruction of Creation can be implemented and developed, understood and lived, only where Creation is considered as beginning with God" [10, emphasis mine].

Protection of the environment is thus conditioned by one's belief in who or that which is at the beginning of creation. The misuse of creation begins when human beings no longer recognize any higher instance than themselves alone, and thus using everything simply as their property.

Ecclesial ecocriticism is founded on a communal father or creator of all natures. Ecclesial ecocritics believe that "the world came about as the result of a decision, not from chaos or chance, and this exalts it all the more." [2, \#77]. They believe in the environment or nature as God's gift. Pope Benedict XVI says that "in nature, the believer recognizes the wonderful result of God's creative activity, which we may use responsibly to satisfy our legitimate needs, material or otherwise, while respecting the intrinsic balance of creation. If this vision is lost, we end up either considering nature an untouchable taboo or, on the contrary, abusing it." [7, \#48]. The way one thinks or believes dictates one's behavior. If nature comes from God and is given to humanity, then in the way we use it we have a responsibility towards future generations and towards God. Expatiating on this responsibility, the Pope[7] writes: "Human beings legitimately exercise a responsible stewardship over nature, in order to protect it, to enjoy its fruits and to cultivate it in new ways, with the assistance of advanced technologies, so that it can worthily accommodate and feed the world's population. (...) We must recognize our grave duty to hand the earth on to future generations in such a condition that they too can worthily inhabit it and continue to cultivate it. This means being committed to making joint decisions 'after pondering responsibly the road to be taken, decisions aimed at strengthening that covenant between human beings and the environment, which should mirror the creative love of God, from whom we come and towards whom we are journeying'(120)" [7, \#50, italics are the author's].

Faith in God as the Creator of nature is then the fourth characteristic to be taken into account in ecclesial ecocriticism. Nature, as pointed out earlier, is God's gift to his children. The entire human family must handle it with care and responsibility, finding, through hard work and creativity, the resources to live with dignity, through the help of nature itself.

This aspect is so important that, even though Pope Francis[2] is "well aware that in the areas of politics and philosophy there are those who firmly reject the idea of a Creator, or consider it irrelevant, and consequently dismiss as irrational the rich contribution which religions can make towards an integral ecology" [\#62], addressing his document not only to members of the Church but "to all people" [\#3], he deems it necessary to "include a chapter dealing with the convictions of believers" [\#62]. Further observing that "the majority of people living on our planet profess to be believers" Pope Francis[2] says that "this should spur religions to dialogue among themselves for the sake of protecting nature" [\#201]. It is also to this effect that literary devices such as pathetic fallacies are used.

\subsection{Pathetic Fallacy}

One of the above-mentioned characteristics of the theory of ecclesial ecocriticism indicates that it includes human nature within nature in its analysis. The extension of humanity into the 'environment' makes possible an interaction whereby human features are attributed to nature 
and natural realities to human beings. Metaphoric language such as pathetic fallacy and personification then indicate that human beings have a place in the universe. Indeed, the "motive for metaphor may be as Frye claims, 'a desire to associate, and finally to identify, the human mind with what goes on outside of it' " [8, p19].

There are two types of pathetic fallacies: one consists in the "ascription of human traits to inanimate nature" [11, p122] or any nature in the environment; the other in the attribution of nature's potentials to human beings. In other words, it is a matter of humanization of nature, on the one hand, and of the naturalization of human beings on the other hand. General literary theory of ecocriticism usually minds the first while that of ecclesial ecocriticism takes both into account.

As a follow-up, this excerpt from ecclesial literature on climate change displays a mind-arresting pathetic fallacy of the first category whereby Pope Benedict[7] attributes some human qualities to nature: "Nature expresses a design of love and truth. It is prior to us, and it has been given to us by God as the setting for our life. Nature speaks to us of the Creator. [...] It is a wondrous work of the Creator containing a 'grammar' which sets forth ends and criteria for its wise use, not its reckless exploitation" [\#48].

Nature is endowed with human senses: it speaks, loves, has a grammar, and a lot of other things, similar to human beings. It is not just matter for us to shape at will. It has a dignity of its own, which we must respect and submit to its directives. Its language should be listened to and obeyed.

In Laudato Si, Pope Francis[2] is more pathetic when he says that "the violence present in our hearts, wounded by sin, is also reflected in the symptoms of sickness evident in the soil, in the water, in the air and in all forms of life." [\#2] All elements in the environment are in direct correlation and interaction with one another to the extent that one of them, namely human nature, causes the others to suffer. The earth is ailing as any human being. She is referred to as a mother, "groaning in travail" [Rom 8:22].

Owing to this attribution of a common father to all natures and the belief in creation in the explanation of the origin of the world, all other elements in mother earth become human beings' brothers and sisters. Thus, we have "brother sun, sister moon, brother river" [2, \#92]. This fraternity is so strong that morality comes into account in human beings' relationships or interactions with natures in the environment. For instance, Pope Francis[2] says that, "for human beings to contaminate the earth's waters, its land, its air, and its life - these are sins" [\#8]. The Pope sees climate change as a moral issue of burning importance that puts creation into danger and places more burdens on poor people, and thus compromises the common good of all. He invites human beings, within the scope of universal brotherhood, to "feel the desertification of the soil almost as a physical ailment, and the extinction of a species as a painful disfigurement" [2, \#89]. If the suffering of other elements in nature is reflected in human nature's feelings, then the interconnection between natures in the environment (second characteristic of ecclesial ecocriticism) is reciprocal. A misbehavior of one affects all others dangerously. On the other hand, when all behave, all live in perfect harmony together.

Pathetic fallacy of the second category, namely the naturalization of human beings (which is the first characteristic of ecclesial ecocriticism) appears in ecclesial literature on climate change. In Laudato Si, for example, Pope Francis[2] brings the naturalization of human nature into prominent salience when he urges us recognize that "the way natural ecosystems work is exemplary: plants synthesize nutrients which feed herbivores; these in turn become food for carnivores, which produce significant quantities of organic waste which give rise to new generations of plants" [\#22]. The natural ecosystem should serve as example for men and women. Our industrial system should try to get inspiration from natural ecosystems in by adopting a circular model at the end of its cycle of production and consumption, developing the capacity to absorb and re-use waste and by-products. This emerges as the new type of pathetic fallacy, i.e., the ascribing of nature's traits to human beings that the theory of ecclesial ecocriticism sets forth.

The Church herself is an imitator of nature. For instance, with regards to family planning or population control, the Catholic Church advocates a natural method, as if to say "imitate nature, do as nature does," rejecting then abortion, artificial contraception and sterilization. The man-made methods can but lead to nature's destruction or disturbance of its natural ecosystem, with glaring offshoots of ageing population in some European countries addicted to such methods, or the outnumbering of boys over girls in China for example. Such artificial and widespread methods not only harm the environment in processing them, but also bring human nature close to chaos, following suit to the extinction of some species of animals or plants. The way out is to foster intimacy with nature, in other words, becoming natural.

The two types of pathetic fallacies are interconnected, especially in the ecclesial literature on climate change. One can see this connection in the fact that the Catholic Church's ecocriticism demands the reader to be capable of hearing "both the cry of the earth and the cry of the poor" [2, \#49], as they echo or call for one another. In fact, ecology applies to both the earth and man alike. Traditional ecological approaches and sociological approaches go hand in hand in ecclesial ecocriticism. Pope Francis[2] claims that when human beings fail to consider "the worth of a poor person, a human embryo, a person with disabilities to offer just a few examples - it becomes difficult to hear the cry of nature itself; everything is connected" [\#117]. Ecclesial ecocriticism is holistic.

\section{Conclusions}

Insofar as general literary "ecocriticism seeks to redirect 
humanistic ideology, not spurning the natural sciences but using their ideas to sustain viable readings, [as both] literature and science trace their roots to the hermeneutics of religion and law" [6, p78], there is a place for the theory of ecclesial literary ecocriticism. One is applicable to literary writings, and the other to religion-related literature. The specificities of the latter, upon examination of ecclesial literature on climate change, are the restoration of human nature within the other natures, the consideration of the interdependence of natures, the attribution of the authorship of natures to God, and drawing the attention that nature's protection is intrinsically dependent on one's belief in its origin. Ecclesial theory of ecocriticism can be seen as one of the comprehensive solutions to nature's problems. In Pope Francis[2]'s analysis, as "we are faced not with two separate crises, one environmental and the other social, but rather with one complex crisis which is both social and environmental" [\#139], only comprehensive solutions that take into account the interactions within social systems and natural systems themselves are salutary options. Therefore, this theory of ecclesial ecocriticism illuminates the Bible and religious classics, thus forming believers' consciousness to take care of the earth, our common home.

\section{REFERENCES}

[1] Cheryll Glotfelty. "Introduction: Literary Studies in an Age of Environmental Crisis" in Glotfelty, Cheryll and Fromm Harold, eds. The Ecocriticism Reader: Landmarks in Literary Ecology, The University of Georgia Press, Georgia, xv-Xxxvii, 1996.
[2] Pope Francis. Laudato SI, Praised be: Encyclical letter of the Holy Father Francis on Care for our Common Home, Veritas, Dublin, 2015.

[3] David Rothwell. A to Z of English Literature, Wordsworth Edition Limited, Hertfordshire, 2010.

[4] Peter, Barry. Beginning Theory: An Introduction to Literary and Cultural Theory, Third edition, Manchester University Press, Manchester, 2009.

[5] Lawrence Buell, Ursula K. Heise, and Karen Thornber. "Literature and the Environment", The Annual Review of Environment and Resources, Online available from http://www.environ.annualreviews.org.

[6] William Howarth. "Some Principles of Ecocriticism", in Glotfelty, Cheryll and Fromm Harold, eds. The Ecocriticism Reader: Landmarks in Literary Ecology, The University of Georgia Press, Georgia, 69-89, 1996.

[7] Pope Benedict XVI. Encyclical letter Caritas in Veritate on Integral Human Development in Charity and in Truth, Libreria Editrice Vaticana, Vatican, 2009.

[8] Neil Evernden. "Beyond Ecology: Self, Place, and Pathetic Fallacy." The North American Review, Vol 263, № 4, 16-20, 1978.

[9] Rigby, Kate. "Earth, World, Text: On the (Im) possibility of Ecopoiesis", New Literary History, Vol. 35, 427-442, 2004.

[10] Sandro Magister, "The Pope Theologian Says: The Proof of God Is Beauty", August 11, 2008, Online available from http://chiesa.espresso.repubblica.it/articolo/206168?eng=y\&r efresh_ce.

[11] M. H. Abrams. A Glossary of Literary Terms, third edition, Holt, Rinehart and Winston, London, 1971.

[12] Tara C Trapani. "The Forum on Religion and Ecology at Yale," Online available from http://fore.yale.edu/climate-cha nge/statements-from-world-religions/christianity/. 